THE THEORY OF ECONOMIC GROWTH 


\title{
The Theory of Economic Growth
}

\author{
An Introduction
}

\author{
GRAHAM HACCHE
}

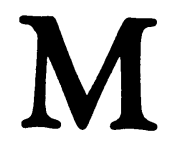

Macmillan Education 
(C) Graham Hacche 1979

All rights reserved. No reproduction, copy or transmission of this publication may be made without written permission.

No paragraph of this publication may be reproduced, copied or transmitted save with written permission or in accordance with the provisions of the Copyright Act 1956 (as amended), or under the terms of any licence permitting limited copying issued by the Copyright Licensing Agency, 7 Ridgmount Street, London WC1E 7AE.

Any person who does any unauthorised act in relation to this publication may be liable to criminal prosecution and civil claims for damages.

First published 1979

Reprinted 1985, 1987

Published by

MACMILLAN EDUCATION LTD

Houndmills, Basingstoke, Hampshire RG21 2XS

and London

Companies and representatives

throughout the world

British Library Cataloguing in Publication Data

Hacche, Graham

Theory of economic growth.

1. Economic development

I. Title

$339.5 \quad$ HD82

ISBN 978-0-333-23571-3 ISBN 978-1-349-16221-5 (eBook)

DOI 10.1007/978-1-349-16221-5 
To my parents 


\section{Contents}

\section{PART I INTRODUCTION}

1 The Emergence of Modern Growth Theory-

The Harrod-Domar Models

1.1 Harrod, Domar and Keynes 3

1.2 Harrod's model in outline 4

1.3 The implications of Harrod's model: equilibrium growth as an unlikely and unstable coincidence 8

1.4 Harrod and the theory of the business cycle 13

1.5 Domar's model, and a summary of Harrod-Domar 16 Further reading

2 The Development of Modern Growth Theory A Preview 20

2.1 What is 'growth theory' about? 20

2.2 The steady state as a device of dynamic theory 22

2.3 The empirical relevance of steady states 25 Further reading 28

\section{PART II NEO-CLASSICAL GROWTH THEORY}

3 Fixed versus Variable Coefficients -

The Neo-classical Approach

3.1 Harrod-Domar again 31

3.2 The neo-classical reaction $\quad 34$ 
viii

4 The One-good Model without Technical ProgressThe Simplest CASE $\quad 37$

4.1 The model 37

4.2 The existence and uniqueness of steady-state equilibrium 41

4.3 Comparing steady states 44

4.4 The stability of the steady state: equilibrium dynamics 51

4.5 Summary 53

Further reading $\quad 54$

5 The One-good Model without Technical Progress -

Altering SOME ASSUMPTIONS

5.1 Introduction $\quad 55$

5.2 The saving function $\quad 55$

5.3 The labour force $\quad 62$

5.4 The production function 63

5.5 A monetary asset $\quad 69$

$\begin{array}{ll}5.6 \text { Depreciation } & 78\end{array}$

$\begin{array}{ll}\text { Further reading } & 79\end{array}$

6 The Two-sector Model without Technical Progress 80

6.1 Introduction: relaxing the one-good assumption 80

6.2 The model $\quad 82$

6.3 Momentary equilibrium $\quad 83$

6.4 The existence and uniqueness of steady-state
equilibrium

6.5 The stability of steady-state equilibrium 92

6.6 Conclusion 96

Further reading $\quad 97$

7 Technical Progress, Productivity Growth and STEADY STATES 99

7.1 Technical progress and modern economic growth 99

7.2 Disembodied technical progress at an exogenous rate 100

$\begin{array}{lll}7.3 & \text { Requirements for steady growth } & 101\end{array}$

7.4 Steady growth with technical progress 105

7.5 Alternative notions of neutrality and bias 107 
7.6 Embodied technical progress at an exogenous rate: vintage models

7.7 The importance of technical progress: accounting for growth

Further reading

8 Technical Progress - Theories of Bias and

NEUTRALITY

8.1 Introduction

120

8.2 The Hicks-Ahmad theory of induced Hicks-bias

8.3 The Kennedy theory of Harrod-neutrality

8.4 The neo-classical one-sector model with endogenous Harrod-neutrality

8.5 Summary and conclusions

9 Technical Progress at an Endogenous Rate

9.1 The stages and sources of technical progress

9.2 Learning by doing

9.3 Kaldor's technical progress function

9.4 The frontiers of steady-state equilibrium analysis and beyond

Further reading

\section{PART III NEO-KEYNESIAN GROWTH THEORY}

10 Neo-Keynesian Criticisms of Neo-classical Theory 161

10.1 The neo-Keynesian heritage: Keynes and the classics 161

10.2 Keynes

10.3 Competition, markets and prices $\quad 171$

10.4 Saving: Kalecki and the classics $\quad 173$

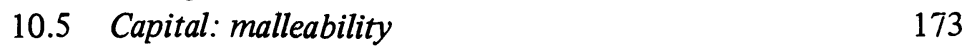

$\begin{array}{ll}10.6 \text { Capital: homogeneity } & 178\end{array}$

$\begin{array}{lll}10.7 & \text { Summary } & 181\end{array}$

Further reading $\quad 183$ 
11 Income Distribution ANd Effective Demand 185

11.1 Introduction 185

11.2 Distribution determined by the degree of monopoly (Kalecki)

11.3 Distribution determined by investment and saving (Kaldor)

11.4 Investment and external constraints on distribution 198

11.5 Distribution as a determinant of output

12 Full Employment, Saving and the Flexibility of

Profit MARgins

204

12.1 The stability of full employment in neo-Keynesian theory

12.2 The neo-Keynesian saving function 214

12.3 The rate of profit and the Pasinetti Paradox 220

12.4 The flexibility of profit margins 224

13 InVestment and Growth - Kaldor's Growth Model

13.1 Introduction 228

13.2 Period analysis: steady-state solution 228

13.3 Period analysis: stability of steady growth 235

13.4 Continuous analysis $\quad 240$

13.5 Vintage capital and the pay-off period 245

13.6 Conclusion 247

PART IV STEADY GROWTH AND ECONOMIC HISTORY

14 Stylised Facts, Steady Growth and Structural

CHANGe

14.1 Kaldor's stylised facts and steady growth 251

14.2 Structural change and a missing stylised fact 255

15 Stylised Facts and Historical Statistics 260

15.1 Introduction 260

15.2 Capital statistics: problems and methods 260 
15.3 Output, capital and employment

15.4 Distributive shares and the rate of profit

15.5 Conclusions

298

Notes and References

301

Bibliography

326

Index 


\section{Preface}

The purpose of this book is to provide an introductory but fairly comprehensive account of the modern theory of economic growth. The exposition assumes no prior knowledge of growth theory, but it does assume that the reader is acquainted with the principles of macro- and micro-economics; it is intended mainly for undergraduates, beyond their first year, and graduate students. Elementary differential calculus is used extensively, and integral calculus occasionally; it will therefore be helpful, to say the least, if the reader is familiar with these branches of mathematics. (The usual introductory mathematics course for university economics students, for example, should have equipped him with most of the tools he will need.) But I have tried generally to supplement the mathematics with verbal explanation, and I hope that the non-mathematician will not feel shut out.

The book is concerned with the descriptive aggregative growth theory which has stemmed from the work of Harrod and Domar; for treatments of both multi-sector (or non-aggregative) and optimal growth theory (which may be traced back to the work of von Neumann and Ramsey, respectively) the reader is referred to more advanced tex ts - for example the second half of Burmeister and Dobell (1970). This book attempts to provide a fairly comprehensive account of the field thus defined, and it is hoped that it will be found useful as such by the reader who lacks the time to benefit from much study of the original sources. The more serious specialist will not trust or be satisfied with my exposition alone; for him, it is hoped that what follows will assist and guide the reading of the literature. (Some chapters - particularly those in which certain subjects are treated only briefly - are accompanied by supplementary lists of references suggesting possibilities for further reading.) 
There are two particular respects in which the content of this book differs from that of most other texts on the subject. First, it provides a fuller account of the 'neo-Keynesian' approach to growth theory. Most textbooks allocate by far the greater part of their space to the 'neoclassical' approach, and provide at most one or two chapters - sometimes even only one or two pages - for a discussion of neo-Keynesian theory. I have attempted to provide a more balanced treatment of the differences between the two schools, and in so doing have included a fuller account than usual of the constructive (as opposed to the critical) efforts of neo-Keynesian theorists. Their critique of neo-classical theory is discussed partly in Chapter 9 but mainly in Chapter 10; together these two chapters may be regarded as forming a bridge between the neoclassical analysis of Chapters 4-8 and the neo-Keynesian theory of Chapters 11-13. Second, whereas most other textbooks have negligible empirical content, I have attempted, in Chapters 14 and 15, to provide an introduction to applied analysis by considering the empirical interpretation of the theory and some of the problems involved in confronting the theory with data. How is growth theory related to growth in real economies? What does growth theory tell us about economic history and vice versa? These questions are worthy of consideration. They are, indeed, worthy of more consideration than I have managed to give them: despite Part IV this book does no more than scratch the surface of empirical growth analysis.

As a student at Cambridge in the late 1960s, I would have found it difficult to ignore the theory of economic growth. More specifically, I owe my original interest in the subject to the lectures and teaching of Professor Kaldor and David Newbery. The book began to develop when I was a graduate student at Oxford, and it owes a considerable debt to the advice of my supervisor, Nicholas Stern; it would have foundered at a very early stage without his encouragement. David Newbery, Roger Pownall, Maurice Scott, Susan Symes and Tony Thirlwall provided valuable comments on parts or the whole of the draft at various stages. My debt to the written work of, in particular, Professors Hicks, Kaldor, Meade, Robinson and Solow will be obvious from the bibliography and also, I hope, from the text. Last, but not least, I am grateful to my employers, the Bank of England, and in particular to Leslie Dicks-Mireaux and Tony Carlisle, for their co-operation, and for their toleration of the distraction which this project has formed at various times while I have been with them. The charts were drawn, under the supervision of Amy Crosby, mainly by Gill Fitzgerald, Amanda Waldie, and Susan 
Taylor; the typing of the final manuscript, organised by Jenny Bunkall, was done mainly by Hilary Abbott, Diane Coombs, Christine Hale, Glenys Harris and Lynne Ross. I am very grateful for their help.

It goes without saying that no part of the book - not even those parts which are right - necessarily reflects any Bank of England view, and that I alone am responsible for the final product.

July 1978

Graham Hacche 